\title{
Ecotoxicity of mercury to Folsomia candida and Proisotoma minuta (Collembola: Isotomidae) in tropical soils: Baseline for ecological risk
} assessment

\author{
Andressa Cristhy Buch ${ }^{\mathrm{a}, *}$, Júlia Carina Niemeyer ${ }^{\mathrm{b}}$, Maria Elizabeth Fernandes Correia ${ }^{\mathrm{c}}$, \\ Emmanoel Vieira Silva-Filho ${ }^{\text {a }}$ \\ a Department of Environmental Geochemistry, Fluminense Federal University, Outeiro São João Baptista, s/n., Centro, 24020-007, Niterói, RJ, Brazil \\ b Programa de Pós Graduação em Ecossistemas Agrícolas e Naturais (PPGEAN), Federal University of Santa Catarina, Center of Curitibanos, Rod. Ulysses \\ Gabordi, km 3, 89520-000, Curitibanos, SC, Brazil \\ c Embrapa Agrobiology, BR 465 km 7, 23890-000 Seropédica, RJ, Brazil
}

\section{A R T I C L E I N F O}

\section{Article history:}

Received 29 September 2015

Received in revised form

11 January 2016

Accepted 11 January 2016

Available online 19 January 2016

\section{Keywords:}

Autochthonous species

Ecotoxicological tests

Invertebrates soil fauna

Springtail

Trace metal

\begin{abstract}
A B S T R A C T
Mercury (Hg) is a highly toxic nonessential trace metal. Despite its natural occurrence in the Earth's Crust, its concentrations have been steadily increasing in the environment due to anthropogenic sources. Recent studies have showed great concern about soil fauna, once the potential adverse effects of mercury concentrations in the environment of these invertebrates are still poorly understood, especially when linked to forest soils and tropical biota. Different collembolan species can show distinct toxicity effects to the contaminants, impairing its developing lifelong and affecting its diversity and abundance in the environment. Laboratory studies were performed to evaluate the ecotoxicity of $\mathrm{Hg}(\mathrm{II})$ to collembolan species collected in Brazil, Proisotoma minuta (autochthonous) and Folsomia candida (allochthonous), as a tool to predict effects in ecological risk assessment of tropical regions. Behavioral, acute and chronic tests were carried under temperatures of $20^{\circ} \mathrm{C}$ and $24^{\circ} \mathrm{C}$ using two test soils, natural and artificial, spiked with increasing mercury concentrations. F. candida was more sensitive to mercury contamination than $P$. minuta, presenting the most restrictive values of $\mathrm{EC}_{50}$ and $\mathrm{LC}_{50}$. Reproduction was a considerably more sensitive endpoint than avoidance and mortality. The 28-day lower $\mathrm{EC}_{50}$ values were found in chronic tests for F. candida in natural soil to $24{ }^{\circ} \mathrm{C}\left(3.32 \mathrm{mg} \mathrm{Hg} \mathrm{kg}^{-1}\right)$, while for $P$. minuta was in tropical artificial soil to $20^{\circ} \mathrm{C}\left(4.43 \mathrm{mg} \mathrm{Hg} \mathrm{kg}^{-1}\right)$. There were similarity for each collembolan species to respond at the $\mathrm{Hg}$ (II) effects when exposed at $20^{\circ} \mathrm{C}$ and $24^{\circ} \mathrm{C}$. F. candida can be suitable as a bioindicator species to mercury ecotoxicity tests in tropical forest soils.
\end{abstract}

(c) 2016 Elsevier Inc. All rights reserved.

\section{Introduction}

Since the industrial revolution the levels of mercury $(\mathrm{Hg})$ have been increasing in the atmosphere and environment. Anthropogenic sources are responsible for about $30 \%$ of annual emissions of mercury to air. Another 10\% comes from natural geological sources, and $60 \%$ is from "re-emissions" of these sources previously released mercury that has built up over decades and centuries in surface soils and oceans (UNEP, 2013). Mercury is considered a global pollutant with ability to undergo long distance transportation in the atmosphere and to be easily redistributed in terrestrial and aquatic ecosystems (Marumoto et al., 2015; SilvaFilho et al., 2006). Mercury deposition in these ecosystems can be

\footnotetext{
* Corresponding author.

E-mail address: andressabuch@hotmail.com (A.C. Buch).
}

carried out by dry and/or wet processes, via particulate materials, rain and fog, respectively, and also gaseous exchange between the air, water and soil (Juillerat et al., 2012). More than 90\% of atmospheric mercury (elemental and reactive) is absorbed by forests being potentially a large mobile reservoir that may $\mathrm{Hg}$ provide to terrestrial and aquatic fauna (Grigal, 2003; Richardson et al., 2013). Recent studies have reported the accumulation of atmospheric $\mathrm{Hg}$ in tropical forest soils, remaining in greater quantity in litter and soil (Silva-Filho et al., 2006; Teixeira et al., 2012; Buch et al., 2015).

All soils are in some extent contaminated by global mercury pollution, due to the relatively long lifetime of $\mathrm{Hg}$ in the atmosphere, which means that the metal can travel long distances before being oxidized and deposited (Schroeder and Munthe, 1998; Liu et al., 2014). The soils have a high ability to retain and store $\mathrm{Hg}$ in function of the strong coupling of this with the carbon in the soil, providing favorable conditions for the formation of inorganic mercury compounds, such as mercury $(\mathrm{OH})$ and also 
Table 1

Summary of characteristics of Folsomia candida and Proisotoma minuta.

\begin{tabular}{|c|c|c|}
\hline Species & Folsomia candida (Willem, 1902) & Proisotoma minuta (Tullberg, 1871) \\
\hline \multicolumn{3}{|l|}{ Morphology $^{\mathrm{a}, \mathrm{b}}$} \\
\hline Body length & $\approx 2.8 \mathrm{~mm}$ & $\approx 1.2 \mathrm{~mm}$ \\
\hline Pigment body & white & Greyish brown \\
\hline PAO & Present & Present \\
\hline Eye & Ocelli absent & $8+8$ ocelli \\
\hline Abdomen & Abd IV/V and VI fused & Abd V and Abd VI separate \\
\hline Anal spines & Absent & Absent \\
\hline Furca & Present & Present \\
\hline Manubrium & $\begin{array}{l}\text { Ventral side with numerous setae (at least } 8+8 \text { and up to } \\
16+16)\end{array}$ & Ventral side with $1+1$ apical setae \\
\hline Dens & Ventral side with about 28 setae & Dorsal side with ridges \\
\hline Mucro & Two teeth & Three teeth \\
\hline \multicolumn{3}{|l|}{ Life history traits in laboratory cultures $\left(20 \pm 2^{\circ} \mathrm{C}\right)$} \\
\hline Time until oviposition after egg-hatching & 20-25 days & 18-20 days \\
\hline Time of egg development & 10 days & 8 days \\
\hline Stage to exposure & Juvenile (10-12 days) & Juvenile (10-12 days) \\
\hline $\begin{array}{l}\text { Optimal growth and reproduction conditions of } \\
\text { temperature }\end{array}$ & $20 \pm 2{ }^{\circ} \mathrm{C}$ & $20 \pm 2{ }^{\circ} \mathrm{C}$ \\
\hline Reproduction $^{\mathrm{a}, \mathrm{b}}$ & Asexual & Sexual \\
\hline \multicolumn{3}{|l|}{ Environment $^{\mathrm{a}, \mathrm{c}}$} \\
\hline Distribution & Cosmopolitan, widely found in temperate regions & Cosmopolitan, widely found in tropical regions \\
\hline Ecological-group & Hemiedaphic (soil-litter interface) & Hemiedaphic (soil-litter interface) \\
\hline Soil condition & Decaying organic matter & Decaying organic matter \\
\hline Land use & Agriculture, forestry and pasture & Agriculture, forestry and pasture \\
\hline
\end{tabular}

\footnotetext{
a Hopkin (2007).

${ }^{\mathrm{b}}$ Fjellberg (2007).

c Mendonça et al. (2015)
}

$\mathrm{HgCl}$, and the mercuric cation coming from of complex compounds with organic anions (Soares et al., 2015). According to KabataPendias (2011) the residence time of $\mathrm{Hg}$ in the soil can be estimated between 500 to 1000 years. Approximately three-quarters of biospheric mercury resident in soils is mainly in the species of inorganic mercury ( $\mathrm{Hg}$ I or II), which tend the bioaccumulate and biomagnificate to methylmercury, posing risk to plants, invertebrates and microorganisms (Tipping et al., 2011).

Soil fauna has fundamental role in the soil structure, decomposition process and enhancement of primary production (Quijas and Balvanera, 2013). The continued exposure of these invertebrates to pollutants may result in morphological, physiological and behavioral changes to species more sensitive, causing an unbalance of populations and consequently impairment of ecosystem functioning (Santorufo et al., 2012).

Collembola is one of the most abundant groups in terrestrial ecosystems. They participate in the microfragmentation of plant detritus and stimulate the activity of bacterial and fungal colonies. In addition, they act in the maintenance of good soil quality, participate in the soil organic matter dynamics and nutrient mineralization, being thus considered excellent bioindicators of forest condition and change (Cassagne et al., 2006; Sterzyńska et al., 2014) and in ecotoxicological studies, once that they are easy to sample and to culture in laboratory conditions (Fountain and Hopkin, 2005).

Approximately 7000 collembolan species have been described in the world (Deharveng, 2004). The tropical forests of countries such as Brazil, Australia and New Zealand are characterized by a high species richness including several endemic species. However, the lack of knowledge about this great biodiversity in species and of its sensibility to environmental contamination may reduce or extinguish species (Lewinsohn and Prado, 2005).

Ecotoxicity of $\mathrm{Hg}(\mathrm{II})$ is still poorly understood for soil fauna, especially in tropical regions. This study evaluated behavioral, acute and chronic effects of $\mathrm{Hg}$ (II) spiked in soils for Collembola aiming to predict effects of mercury atmospheric deposition in forest tropical soils to order of auxiliary scientifically in decisions of ecological risk assessments (ERA) and of risk management of contaminated sites.

\section{Materials and methods}

\subsection{Sampling of collembolans and culture conditions}

Collembolan species were obtained from forest soils of two Forest Conservation Units of Rio de Janeiro state, Brazil, being Três

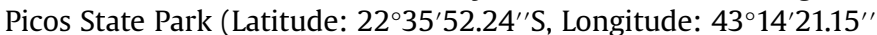
O, altitude: $74 \mathrm{~m}$ ) and Taquara Municipal Natural Park (Latitude: $22^{\circ} 30^{\prime} 8,76^{\prime \prime}$, Longitude: $42^{\circ} 51^{\prime} 21,95^{\prime \prime} \mathrm{O}$, altitude: $72 \mathrm{~m}$ ). Surface dwelling collembolans were collected in eight uncovered pitfall traps (diameter of $7 \mathrm{~cm}$ ) for each site. Traps were placed along a $20 \mathrm{~m}$ transect with a spacing of $5 \mathrm{~m}$ between them and filled with a substrate of plaster of Paris and activated charcoal (10:1) with a water slide surface of $3 \mathrm{~cm}$ depth. Sampled invertebrates from the traps were removed every day over a period of seven days. Thereafter in laboratory, only collembolans were isolated in culture boxes, when the more abundant species were determined to species level, following the dichotomous key of Fjellberg (2007) and Hopkin (2007).

Four collembolan species were isolated and maintained in laboratory: Proisotoma minuta (Tullberg, 1871) present on $68 \%$ of samples, Entomobrya sp. - on $17 \%$, Sminthurides sp. - on $13 \%$ and Folsomia candida (Willem, 1902) on $2 \%$ of samples. This last specie was selected because its use as a standard test organism to assessment soil quality by ISO guidelines. Collembolans were cultured in plastic containers lined with a mixture of plaster of Paris and activated charcoal 8:1 (ISO, 1999) under temperature of $20 \pm 2{ }^{\circ} \mathrm{C}$ and with a photoperiod of $12: 12 \mathrm{~h}$ light:dark. Cultures were kept moistened and a small amount of granulated dry yeast 
was added as a food source once a week. A better development of cultures of Sminthurides sp. and Entomobrya sp. were observed after insertion of moss (approximately $1 \mathrm{~g}$ ), revealing a habitat and food preference for this material.

Sminthurides sp. did not reproduce in laboratory during eight months of monitoring, possibly because we found few specimens of males. It is known that in the Family Sminthurididae, the males choose the female and attach themselves with antennae modified for clasping (Niklasson et al., 2000).

Entomobrya sp. (Entomobryidae) survived by two months in laboratory, while the culture declined gradually, indicating low adaptation to laboratory conditions.

For $F$. candida and P. minuta, the establishment of the cultures occurred after four months and they were monitored during one year. Its biological characteristics and life history can be observed in Table 1.

Aiming to assess the sensitivity of $F$. candida and $P$. minuta to mercury, adults were transferred to new boxes with culture substrate for egg-laying to obtain synchronized juveniles (10-12 days old) for the ecotoxicity tests.

\subsection{Test soils}

Two soils were used as test substrate for the ecotoxicological tests: a natural and an artificial soil. The natural soil (NS) was a forest soil collected at $20 \mathrm{~cm}$ top layer from Forest Conservation Unit, Três Picos State Park (Latitude: 22 ${ }^{\circ} 35^{\prime} 52.24^{\prime \prime}$ S, Longitude: $43^{\circ} 14^{\prime} 21.15^{\prime \prime} \mathrm{O}$, altitude: $74 \mathrm{~m}$ ), Rio de Janeiro State, Brazil. The soil was defaunated through two freeze-thawing cycles and mechanically ground and sieved to obtain a $2 \mathrm{~mm}$ fraction. Physical and chemical characterization of soil were performed by Brazilian Agricultural Research Corporation - EMBRAPA-Agrobiology, following the methods described in Nogueira and Souza (2005), and the water holding capacity (WHC) was determined according to ISO (1999). The natural soil (NS) was classified as Dystrophic Ta Haplic Cambisol, according to EMBRAPA (2013), being predominant in crop fields and forest soils in Brazil. Properties of NS are shown in Table 2. Low mercury concentrations were detected in the soil samples (Table 2), and such natural budget concentrations were considered to spike the tested soils.

The artificial soil used was proposed by OECD (1984) and adapted by (Garcia et al., 2004, 2011) as a Tropical Artificial Soil (TAS), composed by $70 \%$ of fine sand, $20 \%$ of kaolinite clay and $10 \%$ of powdered coconut fiber, this was used as source of organic matter replacing the sphagnum peat. When necessary the $\mathrm{pH}$ value was adjusted to $6.0 \pm 0.5$ with calcium carbonate.

\subsection{Ecotoxicity tests}

Synchronized collembolans of 10-12 days old were exposed to

Table 2

Physicochemical parameters of natural soil (NS) used in this study

\begin{tabular}{ll}
\hline Soil parameters & Value \\
\hline pH $(1 \mathrm{M} \mathrm{KCl})$ & $3.98 \pm 0.4$ \\
Water holding capacity & $59 \pm 0.8$ \\
Mercury concentration $\left(\mathrm{mg} \mathrm{kg}^{-1}\right)$ & $0.05 \pm 0.004$ \\
Cation exchange capacity $\left(\mathrm{cmol}_{\mathrm{c}} \mathrm{kg}^{-1}\right)$ & $9.63 \pm 0.2$ \\
Electrical conductivity $\left(\mu \mathrm{Sm}^{-1}, 1: 5\right)$ & $70.8 \pm 0.3$ \\
Organic matter (\%) & $2.6 \pm 0.2$ \\
Texture (\%) & \\
Sand & 50 \\
Silt & 15 \\
Clay & 35 \\
\hline
\end{tabular}

\pm Standard Deviation. mercury concentrations added to natural and artificial soil. $\mathrm{Hg}(\mathrm{II})$ was added and hand-homogenized to the soil as aqueous solutions of chloride salt $\left(\mathrm{HgCl}_{2}\right.$, Sigma-Aldrich, St Louis, MO, USA). Mercury nominal concentrations were based on previous studies (e.g., Lock and Janssen, 2001): 0, 0.5, 1, 1.8, 3.2, 5.6, 10 and $16 \mathrm{mg} \mathrm{Hg} \mathrm{kg}^{-1}$ dry weight. Controls received just deionized water. The moisture of soils was adjusted to $50-60 \%$ of the maximum WHC. Tests were performed on cylindrical glass containers $(10 \mathrm{~cm}$ diameter and $8 \mathrm{~cm}$ height). Ecotoxicity tests were conducted with a 12:12 (light/ dark) photoperiod.

\subsubsection{Behavioral tests}

Avoidance tests were carried out according to ISO 17512-2 (ISO, 2011) for each tested soil (TAS and NS) at $20 \pm 2{ }^{\circ} \mathrm{C}$. Each treatment had 5 replicates.

Test containers were divided in two sides by a lamina glass divider inserted transversally in the middle position. One section was filled with $30 \mathrm{~g}$ dry weight of control soil (TAS or NS) and the other side was filled with $30 \mathrm{~g}$ of contaminated soil (TAS or NS). After soil addition, the divider was removed and twenty juvenile springtails (10-12 days old juvenile) were carefully placed in the midline of the container. Containers were covered with an opaque plastic film to reduce water loss by evaporation and to prevent springtails from scape. At the end of the test period ( $48 \mathrm{~h}$ ), the control and test soils in each container were separated by the lamina glass divider. Both soils were flooded with water in separated containers. After the addition of some drops of ink and gently stirring it with a spatula, the springtails floating on the water surface were counted. The tests would be invalid if the number of dead or missing springtails were $>20 \%$ per treatment.

\subsubsection{Acute tests}

The acute toxicity of $\mathrm{Hg}$ (II) to $F$. candida and P. minuta was assessed following the ISO 11267 (ISO, 1999). The lethality tests were carried out during 14 days at $20 \pm 2{ }^{\circ} \mathrm{C}$ and $24 \pm 2{ }^{\circ} \mathrm{C}$. Containers were filled with $30 \mathrm{~g}$ of TAS and/or NS (fresh weight - FW) containing the mercury concentrations (treatments) or deionized water (controls). Five replicates were prepared per treatment. At the start of the test, 10 collembolans were introduced in each experimental unit and about $2 \mathrm{mg}$ of granulated dry yeast was added as food in each glass container. All the containers were covered with parafilm. Once a week, containers were opened to allow gas exchange. At the 14th day, the content of each container was carefully transferred to a larger container, which was filled with water, such that the surviving individuals floated on the water surface. Drops of black ink were added to increase the visual contrast between collembolans and the liquid. Collembolans were counted and the lethality for each treatment was recorded. Due to the rapid degradation of dead springtails, missing organisms are assumed to have died during the test period. The tests would be invalid if the number of dead or missing springtails were $>20 \%$ in controls.

\subsubsection{Chronic tests}

Reproduction tests were carried out according to ISO 11267 (ISO, 1999), evaluating the responses of $F$. candida and $P$. minuta in TAS and NS, at $20 \pm 2{ }^{\circ} \mathrm{C}$ and $24 \pm 2{ }^{\circ} \mathrm{C}$. One day before starting the tests, the test organisms were acclimatized on TAS or NS. The test design was composed by seven $\mathrm{Hg}$ (II) concentrations and the control (distilled water) $\times$ two species $\times$ two temperatures, using five replicates with collembolans. Three additional test containers for each concentration, but without organisms were used for $\mathrm{pH}$, moisture content and residual $\mathrm{Hg}$ (II) determinations at the end of the test (28 days). At the start of the test, 10 juvenile springtails (10-12 days old juvenile) and approximately $2 \mathrm{mg}$ of granulated dry yeast were placed in each test container. All containers were 
covered with parafilm and placed within the incubator. Twice a week the test containers were opened briefly to allow the aeration and the moisture was replaced once a week.

\subsection{Mercury concentrations and $\mathrm{pH}$ analysis at the end of chronic exposures}

Measured concentrations of $\mathrm{Hg}(\mathrm{II})$ were determined in soil ( $\left.\mathrm{mg} \mathrm{kg}^{-1}\right)$ at the beginning and at the end of the tests. Soil samples were manually homogenized and analyzed using a Lumex RA$915+$ device, an atomic absorption spectrometer with a pyrolysis unit (RA-915M), where samples matrix were destructed and mercury atoms were counted on an atomic absorption spectroscopy (EPA, 2004). Determination of $\mathrm{pH}$ values was carried out in a 1:2.5 soil:liquid ratio with $1 \mathrm{M} \mathrm{KCl}$, following ISO guideline (ISO, 1999).

\subsection{Data analysis}

Results of avoidance and lethality toxicity tests were expressed as percentage of response organisms, while results of chronic tests were expressed as mean number of juveniles. The percentual effect of avoidance $(A)$ for $\mathrm{Hg}$ (II) concentrations was calculated using the expression: $A=((C-T) / N)^{*} 100$, where $C$ is the number of individuals in the control soil, $T$ is the number of individuals in the test soil and $N$ is the total number of individuals. NOEC (no observed effect concentration) and LOEC (lowest observed effect concentration) for the avoidance tests were estimated by Fisher's Exact test. The concentrations causing 50\% effect $\left(\mathrm{EC}_{50}\right)$ for avoidance and the median lethal concentration $\left(\mathrm{LC}_{50}\right)$ for lethality tests were calculated using probit analysis with PriProbit Software 1.5 (Sakuma, 1998).

NOEC and LOEC values were determined by ANOVA followed by Dunnett's test, differences between control and each concentration were evaluated at $p<0.05$ level (software Minitab ${ }^{\circledR}$ 15.1.0.0).

The $\mathrm{EC}_{50} \mathrm{~s}$ for reproduction were calculated using non-linear regressions, according to Environmental Canada (EC, 2014). The best fitting model was Gompertz, expressed by the expression (extracted from Chelinho et al. (2014)):

$Y=c^{*} \exp \left((\log (0.5))^{*}(\log c o n c / x b)\right.$, where: $Y$ is the number of juveniles, $c$ is the control response, logconc is the log-transformed exposure concentration, $x$ is the estimate of $50 \%$ effect concentration and $\mathrm{b}$ is the scale parameter (estimated between 1 and 4).

Table 3

Summary of the ecotoxicological effects of mercury for collembolan species.

\begin{tabular}{|c|c|c|c|c|c|c|c|}
\hline Species & Toxicity test & Soil-Test & Temp. ${ }^{\circ} \mathrm{C}$ & $\begin{array}{l}\mathrm{EC}_{50} \text { or } \mathrm{LC}_{50} \\
\mathrm{mg} \mathrm{Hg} \mathrm{kg}{ }^{-1} \text { dry wt }\end{array}$ & NOEC & & LOEC \\
\hline \multirow[t]{8}{*}{ Behavior } & F. candida & TAS & 20 & $6.24(4.66-7.82)$ & 1.8 & & \\
\hline & & & & & & 3.2 & \\
\hline & & NS & & $5.44(4.13-6.75)$ & 1.8 & & \\
\hline & & & & & & 3.2 & \\
\hline & P. minuta & TAS & 20 & $7.52(5.28-9.76)$ & 1.8 & & \\
\hline & & & & & & 3.2 & \\
\hline & & NS & & $7.90(5.78-10.02)$ & 3.2 & & \\
\hline & & & & & & 5.6 & \\
\hline \multirow[t]{16}{*}{ Acute } & F. candida & TAS & 20 & $6.99(4.71-9.27)$ & 3.2 & & \\
\hline & & & & & & 5.6 & \\
\hline & & NS & & $6.12(3.74-8.50)$ & 1.8 & & \\
\hline & & & & & & 3.2 & \\
\hline & P. minuta & TAS & 20 & $7.02(5.42-8.62)$ & 3.2 & & \\
\hline & & & & & & 5.6 & \\
\hline & & NS & & $7.16(3.88-10.44)$ & 3.2 & & \\
\hline & & & & & & 5.6 & \\
\hline & F. candida & TAS & 24 & $6.71(5.00-8.42)$ & 3.2 & & \\
\hline & & & & & & 5.6 & \\
\hline & & NS & & $6.06(3.62-8.50)$ & 1.8 & & \\
\hline & & & & & & 3.2 & \\
\hline & P. minuta & TAS & 24 & $6.87(6.10-7.64)$ & 3.2 & & \\
\hline & & & & & & 5.6 & \\
\hline & & NS & & $7.09(5.28-8.90)$ & 1.8 & & \\
\hline & & & & & & 3.2 & \\
\hline \multirow[t]{16}{*}{ Chronic } & F. candida & TAS & 20 & $3.81(3.67-3.95)$ & 1.0 & & \\
\hline & & & & & & 1.8 & \\
\hline & & NS & & $3.40(3.18-3.62)$ & 1.0 & & \\
\hline & & & & & & 1.8 & \\
\hline & P. minuta & TAS & 20 & $4.43(4.28-4.58)$ & 1.8 & & \\
\hline & & & & & & 3.2 & \\
\hline & & NS & & $4.47(4.31-4.64)$ & 1.8 & & \\
\hline & & & & & & 3.2 & \\
\hline & F. candida & TAS & 24 & $3.64(3.48-3.79)$ & 0.5 & & \\
\hline & & & & & & 1.0 & \\
\hline & & NS & & $3.32(3.11-3.54)$ & 1.0 & & \\
\hline & & & & & & 1.8 & \\
\hline & P. minuta & TAS & 24 & $4.47(4.33-4.62)$ & 1.8 & & \\
\hline & & & & & & 3.2 & \\
\hline & & NS & & $4.58(4.43-4.73)$ & 1.8 & & \\
\hline & & & & & & 3.2 & \\
\hline
\end{tabular}

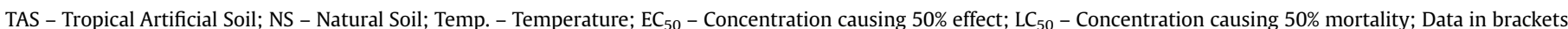
correspond to the $95 \%$ confidence intervals; NOEC - No observed effect concentration; LOEC - Lowest observed effect concentration. 


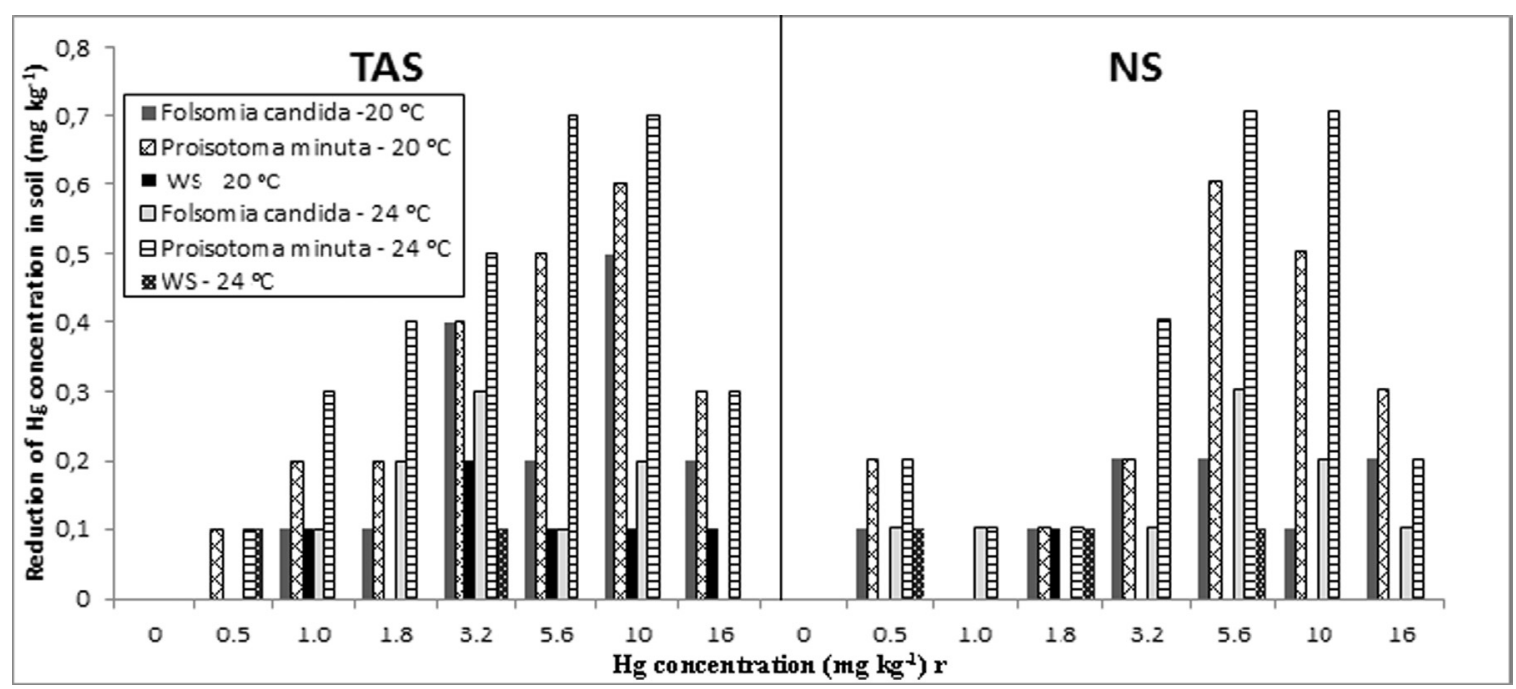

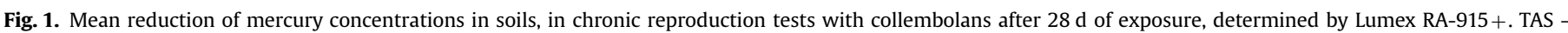
Tropical Artificial Soil; NS - Natural Soil; WS - Treatments without collembolans.

\section{Results}

\subsection{Avoidance responses}

No mortality was observed in all tests. A dose response was observed in the avoidance tests for both tested species towards mercury contamination (showed in Supplementary material, Fig. S1). No avoidance response occurred at $0.5,1.0$ and $1.8 \mathrm{mg} \mathrm{Hg} \mathrm{kg}^{-1}$ dry wt. $\mathrm{EC}_{50}$ values are shown in Table 3 . The most restrictive value was found to $F$. candida in $\mathrm{NS}\left(\mathrm{EC}_{50}=5.44 \mathrm{mg} \mathrm{Hg} \mathrm{kg}^{-1}\right.$ dry wt) and the less restrictive value was to $P$. minuta in NS (EC 50 $=7.90 \mathrm{mg} \mathrm{Hg} \mathrm{kg}^{-1}$ dry wt).

The concentration of $16 \mathrm{mg} \mathrm{Hg} \mathrm{kg}^{-1}$ dry wt showed to be limiting for habitat function of soils for both species, where on average $>80 \%$ of collembolans were found in the control soil.

\subsection{Acute responses}

No lethality of collembolans was found in controls. A dose response was observed in lethality tests for both tested species towards mercury contamination. NOEC, LOEC and derived $\mathrm{LC}_{50}$ are shown in Table 3 . The lowest NOEC value $\left(1.8 \mathrm{mg} \mathrm{Hg} \mathrm{kg}^{-1}\right.$ dry wt) was found in NS for $F$. candida at $20^{\circ} \mathrm{C}$ and at $24^{\circ} \mathrm{C}$, and for $P$. minuta at $24{ }^{\circ} \mathrm{C}$. The derived $\mathrm{LC}_{50}$ ranged from $6.06 \mathrm{mg} \mathrm{Hg} \mathrm{kg}^{-1}$ dry wt (F. candida in NS at $24^{\circ} \mathrm{C}$ ) to $7.16 \mathrm{mg} \mathrm{Hg} \mathrm{kg}^{-1}$ dry wt $(P$. minuta in NS at $24{ }^{\circ} \mathrm{C}$ ). $\mathrm{LC}_{50}$ were similar among species, soils and temperatures.

The concentration of $16 \mathrm{mg} \mathrm{Hg} \mathrm{kg}^{-1}$ dry wt caused $100 \%$ lethality for the tested species in both soils and temperatures (showed in Supplementary material, Fig. S2).

\subsection{Chronic responses}

Reproduction rate in controls reached a minimum of 100 instars per container, with the coefficient of variation lower than $30 \%$, fulfilling the validity criteria of the tests. No significant differences were found for reproduction of each species between tested soils and temperature in controls (one-way ANOVA, Tukey's test, $p<0.05$ ). These findings can indicate that the tested temperatures, $20{ }^{\circ} \mathrm{C}$ and $24^{\circ} \mathrm{C}$, can be in a range of adequate conditions for reproduction of $F$. candida and $P$. minuta (showed in Supplementary material, Fig. S3).

A dose response was observed in reproduction tests for both tested species towards mercury contamination. NOEC, LOEC and derived $\mathrm{EC}_{50}$ are shown in Table 3. Each tested species showed similar response when exposed at $20^{\circ} \mathrm{C}$ or $24^{\circ} \mathrm{C}$. The lower $\mathrm{EC}_{50}$ was found for $F$. candida in NS at $24^{\circ} \mathrm{C}\left(\mathrm{EC}_{50}=3.32 \mathrm{mg} \mathrm{Hg} \mathrm{kg}^{-1} \mathrm{dry}\right.$ wt), while for $P$. minuta the lower $\mathrm{EC}_{50}$ was found in TAS at $20^{\circ} \mathrm{C}$ $\left(\mathrm{EC}_{50}=4.43 \mathrm{mg} \mathrm{Hg} \mathrm{kg}^{-1} \mathrm{dry} \mathrm{wt}\right)$. Reproduction of the species was practically ceased at $10 \mathrm{mg} \mathrm{Hg} \mathrm{kg}^{-1}$ dry wt.

The results evidenced that $F$. candida is more sensitive to mercury contamination than $P$. minuta, and they showed reproduction as the most sensitive endpoint when compared to lethality and avoidance behavior of collembolans to this contaminant.

\subsection{Mercury concentrations and $\mathrm{pH}$ analysis at the end of chronic exposures}

There was no significant variation in $\mathrm{pH}$ values for each soil type in the treatments evaluated, when comparing the start (day 0 ) and the end ( $28 \mathrm{~d}$ ) values of chronic tests. TAS pH values ranged from $5.82( \pm 0.10)$ to $5.79( \pm 0.11)$ at $20^{\circ} \mathrm{C}$ and from $5.80( \pm 0.10)$ to $5.77( \pm 0.14)$ at $24^{\circ} \mathrm{C}$. NS pH values ranged from $3.82( \pm 0.10)$ to $3.76( \pm 0.11)$ at $20{ }^{\circ} \mathrm{C}$ and from $3.80( \pm 0.10)$ to $3.74( \pm 0.11)$ at $24{ }^{\circ} \mathrm{C}$.

At the end of the reproduction test, reduction of $\mathrm{Hg}$ concentrations ( $\mathrm{mg} \mathrm{kg}^{-1}$ ) was higher in the presence of springtails than in replicates without organisms (Fig. 1). Despite not having been measured mercury concentrations in the tissues in springtails, the reduction of these concentrations leads us to believe that the mercury can have been bioaccumulated by collembolans or volatized in the environment. This reduction occurred in both soils tested and the effect was most notorious for replicates with $P$. minuta. Furthermore, it was possible to perceive that for $P$. minuta and $F$. candida the temperature was a factor that contributed to lower values of $\mathrm{Hg}$ in soils at the end of reproduction test (Fig. 1).

\section{Discussion}

In recent years, the searches by new species more representative (in terms of abundance, wide geographic distribution and sensitivity) have been carried out in different regions. Soil metal contamination has been evaluated using common species of temperate regions, in Europe as Folsomia fimetaria (Krogh et al., 2008) and F. candida (Crouau et al., 1999), Orchesella cincta (Van Straalen et al., 1987), endemic species in Asia as Lobella sokamensis 
(An et al., 2013), Paronychiurus kimi (Son et al., 2007b), Onychiurus yodai and Sinella umesaoi (Nakamori et al., 2008), and species from tropical regions in Brazil and Australia as P. minuta (Nursita et al., 2005b; Greenslade and Vaughan, 2003).

P. minuta has been tested in studies of tropical soil quality assessment spiked with trace metals, being considered an important bioindicator of environmental changes, showing high sensitivity to cadmium, copper and zinc (Nursita et al., 2005b) but tolerating high levels of lead (Nursita et al., 2005a) and arsenic (Greenslade and Vaughan, 2003). In the present study, P. minuta was less sensitive than $F$. candida to mercury contamination. These findings could indicate that the ISO standardized tests with $F$. candida are protective of autochthonous species as P. minuta. However, Son et al. (2007b) found that Paronychiurus kimi (common species in Korea) was ten times more sensitive than $F$. candida $\left(E_{50}\right.$ $=0.23 \mathrm{mg} \mathrm{Hg} \mathrm{kg}^{-1}$ dry wt on reproduction tests; $\mathrm{LC}_{50}$ $=2.6 \mathrm{mg} \mathrm{Hg} \mathrm{kg}^{-1}$ dry wt in lethality tests). As the main characteristic of a good indicator is to be sensitive to contaminants, leading to protect the entire community, we can conclude that more knowledge is necessary about sensitivity of native species to contaminants in the tropics.

The resistance to contaminants can be related to the trophic level of the species, its physiology (metal uptake, elimination and immobilization ability), life stages and morphological traits. Presence or absence of hairs/scales can interfere in the bioaccumulation of pollutants, while the presence of sensory and locomotory organs as ocelli, antenna and furca, can help in perception and avoidance when in presence of stressors (Janssens et al., 2009; Salmon and Ponge, 2012). In the environment, ecological groups can show distinct effect-response because inhabit and feed on particular soil layer or stratification, which results on differences in exposure (Salmon et al., 2014). Some collembolans species can show differences in metal sensitivity, decreasing in abundance in direct proportion to the increased concentration, whereas others species can maintain or even increase their population (Santorufo et al., 2012).

$P$. minuta and $F$. candida collected from rainforest successful reproduced in laboratory at either 20 or $24{ }^{\circ} \mathrm{C}$. These results are in accordance with Niemeyer et al. (2015) which reported successful reproduction of $F$. candida in natural soils from Brazil, in laboratory tests incubated at $25^{\circ} \mathrm{C}$. However, Sandifer and Hopkin (1997), evaluating the effects of $\mathrm{Cd}, \mathrm{Cu}, \mathrm{Pb}$ and $\mathrm{Zn}$ in OECD artificial soil to collembolans, reported almost complete inactivity of $F$. candida in chronic tests at $25^{\circ} \mathrm{C}$ even in controls. Other studies demonstrated that the upper limit of tolerance for $F$. candida would be of $26^{\circ} \mathrm{C}$ and some alteration in the ambient temperature could affect its reproduction (Marshall and Kevan, 1962; Snider and Butcher, 1973). The combination of sublethal stress factors, as high (20$35.5^{\circ} \mathrm{C}$ ) or low $\left(0\right.$ to $-7.5^{\circ} \mathrm{C}$ ) temperatures with mercury concentrations $\left(0-48 \mathrm{mg} \mathrm{Hg} \mathrm{L}^{-1}\right)$ can cause an increase in lethality of F. candida (Holmstrup et al., 2008; Slotsbo et al., 2009). Such effects were not observed by the authors when these factors were tested separately, which can indicate a significant potentiation of effects when the temperature is out of the optimum for the species. In the present work, each tested species showed similar response to $\mathrm{Hg}(\mathrm{II})$ in lethality and reproduction when exposed at $20{ }^{\circ} \mathrm{C}$ or $24^{\circ} \mathrm{C}$. The results suggest that the tested temperatures (20 and $24^{\circ} \mathrm{C}$ ) are in a range of adequate condition for the tested species.

A dose response towards mercury contamination was observed in all tests performed. F. candida was more sensitive to mercury contamination than $P$. minuta, presenting the most restrictive values of $\mathrm{EC}_{50}$ and $\mathrm{LC}_{50}$ in both soils and temperatures.

The performance of $F$. candida at $20{ }^{\circ} \mathrm{C}$ in tropical artificial soil with $\mathrm{Hg}(\mathrm{II})$ in chronic and acute tests was similar to that found by Lock and Janssen (2001) in OECD soil. These authors reported EC $_{50}$ value of $3.26 \mathrm{mg} \mathrm{Hg} \mathrm{kg}^{-1}$ dry wt to the 28-day reproduction test and total mortality at $10 \mathrm{mg} \mathrm{Hg} \mathrm{kg}^{-1}$ dry wt, whereas this work observed $\mathrm{EC}_{50}$ and $\mathrm{LC}_{50}$ values of 3.42 and $6.99 \mathrm{mg} \mathrm{Hg} \mathrm{kg}^{-1}$ dry wt, respectively. However, Liu et al. (2010) found different results in a sandy loam soil from China. The $\mathrm{EC}_{50}$ values based on reproduction and avoidance tests with $F$. candida were 9.29 and $3.88 \mathrm{mg} \mathrm{Hg} \mathrm{kg}^{-1}$ dry wt, respectively. Such values for reproduction were higher than the findings of the present work, while avoidance behavior was the most sensitive endpoint.

These dissimilarities could be related to genetic differences between populations. Diogo et al. (2007) found differences in tolerance between laboratory strains of $F$. candida in avoidance behavior towards pesticide exposure, but no differences were found in reproduction. These authors point that the use of clonal lineages from different origins can influence reproducibility of toxicological tests with collembolans.

Furthermore, differences in toxicity can be related to soil properties. In the present study, the tested soils were different in $\mathrm{pH}$ and $\mathrm{OM}$ content. High $\mathrm{pH}$ values and $\mathrm{OM}$ content can increase chemical sorption and consequently decrease bioavailability and toxicity (Sandifer and Hopkin, 1996; Kabata-Pendias, 2011). These parameters can also influence the reproduction of collembolans itself (Son et al., 2007a). The most restrictive value of $\mathrm{EC}_{50}$ was found in reproduction tests with $F$. candida in NS at $24^{\circ} \mathrm{C}$. These findings could be expected due to lower $\mathrm{pH}$ on NS (3.89) in comparison to TAS (6.0), and the lower OM content in NS (3\%) in comparison to TAS (10\%). Luo et al. (2014) evidenced that the low $\mathrm{pH}$ of forest soils may amplify the ecological risk caused by bioaccumulation of lead. Moreover, the type of OM present has influence in bioavailability of contaminants. According to Da Silva et al. (2013), the coconut peat fibers, OM source in TAS, have high ability to retain trace elements due the presence of functional groups such as hydroxyl, carboxyl, and carbonyl. The results reinforce the importance of using natural soils to assess toxicity of contaminants.

Despite bioaccumulation was not determined in this work, the decrease of measured concentrations of $\mathrm{Hg}$ (II) in soil at the end of the chronic test can suggest this occurrence. Results of Nursita et al. (2009) showed a positive correlation between time of exposure and cadmium concentration in tissues of $P$. minuta. Such results may differ among species due to ecological characteristics of the species that modify their exposure, uptake and elimination rates of contaminants. In Bur et al. (2010), F. candida showed cadmium concentration in tissues up to 10 times higher than that measured in the soils to which they were exposed. In the present work, the reduction of measured concentrations of $\mathrm{Hg}$ (II) was more noticeable in replicates with $P$. minuta. Further studies should be carried out to confirm the fate of mercury in soil contamination.

\subsection{Ecological risk assessment (ERA)}

Given of the complexity of an Ecological Risk Assessment (ERA) to mercury contamination in tropical forest soils is necessary the understanding of three investigation lines that are complementary (EA, 2008). A multidisciplinary approach with these lines, chemical, ecological and toxicological, will allow that we can propose environmental and ecological measures to mitigate and even prevent the harmful effects of mercury to soil fauna.

Ecological (quali-quantitative of soil fauna) and chemical ( $\mathrm{Hg}$ levels) information from mercury atmospheric deposition in Forest Conservation Units, of Rio de Janeiro state, Brazil, can be found in Buch et al. (2015). Toxicological data of the most locally representative taxonomic groups are being studied. The present study to Collembola allows us to affirm that not always native species are the most adequate to represent the risks that $\mathrm{Hg}$ 
contamination in soil would entail in collembolans species. So, even being $F$. candida an exotic species, its higher sensitivity help us the further restrict mercury levels to be present in tropical forest soils. Ensuring this way the diversity of a range of species, be native or exotic, and especially protecting the performance of its functionality in terrestrial ecosystems.

\section{Conclusion}

This study attempted to assess the sensitivity to mercury of autochthonous collembolan species most representative of tropical forest soils. Among these collected species Sminthurides sp., Entomobrya sp. and P. minuta, just the last was successful reproduced in laboratory. The standard tested species $F$. candida used in this work for comparisons was also collected and isolated from tropical forest soils and satisfyingly well developed in laboratory conditions, well as at either 20 or $24^{\circ} \mathrm{C}$.

Results showed that $F$. candida was more sensitive to mercury than the autochthonous species $P$. minuta. Among the endpoints evaluated, reproduction presented the most restrictive $\mathrm{EC}_{50}$ values. Each tested species showed similar response in lethality and reproduction when exposed at $20^{\circ} \mathrm{C}$ or $24^{\circ} \mathrm{C}$. The lower $\mathrm{EC}_{50}$ values of $\mathrm{Hg}(\mathrm{II})$ for $F$. candida were found in reproduction tests with the natural soil at $24^{\circ} \mathrm{C}$, while for $P$. minuta were in reproduction tests with the tropical artificial soil at $20^{\circ} \mathrm{C}$.

The results presented in this manuscript can be used in environmental risk of mercury contamination, leading to a more realistic assessment.

This manuscript presents some effects of mercury accumulations in soil to collembolan populations, indicating that concentrations where decrease in abundance can be expected.

\section{Acknowledgments}

The authors thank the financial support of the Foundation for Research Support of the State of Rio de Janeiro (FAPERJ) (E26/ 200.169/2015) by the scholarship for A. Buch, the Brazilian Agricultural Research Corporation (Embrapa-Agrobiology) and the Pascal Querner (of the University of Natural Resources and Life Sciences of Vienna, Austria) by the teaching of biological traits/ taxonomy of Collembola to Buch in the University of Coimbra, Portugal.

\section{Appendix A. Supplementary material}

Supplementary data associated with this article can be found in the online version at http://dx.doi.org/10.1016/j.ecoenv.2016.01. 009.

\section{References}

An, Y.-J., Kim, S.W., Lee, W.-M., 2013. The collembolan Lobella sokamensis juvenile as a new soil quality indicator of heavy metal pollution. Ecol. Indic. 27, 56-60.

Buch, A.C., Correia, M.E.F., Teixeira, D.C., Silva-Filho, E.V., 2015. Characterization of soil fauna under the influence of mercury atmospheric deposition in Atlantic Forest, Rio de Janeiro, Brazil. J. Environ. Sci. 32, 217-227.

Bur, T., Probst, A., Bianco, A., Gandois, L., Crouau, Y., 2010. Determining cadmium critical concentrations in natural soils by assessing Collembola mortality, reproduction and growth. Ecotox. Environ. Saf. 73, 415-422.

Cassagne, N., Gauquelin, T., Bal-Serin, M.-C., Gers, C., 2006. Endemic Collembola, privileged bioindicators of management. Pedobiologia 50, 127-134.

Chelinho, S., Domene, X., Campana, P., Andres, P., Rombke, J., Sousa, J.P., 2014. Toxicity of phenmedipham and carbendazim to Enchytraeus crypticus and Eisenia andrei (Oligochaeta) in Mediterranean soils. J. Soils Sediment. 14,
584-599.

Crouau, Y., Chenon, P. Gisclard, C., 1999. The use of Folsomia candida (Collembola, Isotomidae) for the bioassay of xenobiotic substances and soil pollutants. Appl. Soil. Ecol. 12, 103-111.

Da Silva, K.M.D., Soto, L.C., Rezende, H., Da Silva, C.A., Bergamasco, R., Gonçalves, D. S., 2013. Caracterização físico-química da fibra de coco verde para a adsorção de metais pesados em efluente de indústria de tintas. Engevista 15 (1), 43-50.

Deharveng, L., 2004. Recent advances in Collembola systematics. Pedobiologia 48, 415-433.

Diogo, J.B., Natal-da-Luz, T., Sousa, J.P., Vogt, C., Nowak, C., 2007. Tolerance of genetically characterized Folsomia candida strains to Phenmedipham exposure: a comparison between reproduction and avoidance tests. J. Soils Sediment. 7, 388-392.

EA (Environment Agency), 2008. An Ecological Risk Assessment Framework for Contaminants in Soil. SC070009/SR1. Environment Agency, Bristol, p. 48.

EMBRAPA (Empresa Brasileira de Pesquisa Agropecuária), 2013. Sistema Brasileiro de Classificação de Solos. Centro Nacional de Pesquisa de Solo (Rio de Janeiro RJ). Terceira edição. Rio de Janeiro, p. 286.

EC (Environmental Canada), 2014. Biological test method: test for measuring survival and reproduction of springtails exposed to contaminants in soil, Environmental Technology Centre, Second Edition Environmental Canada, Ottawa, Ontario.

EPA (United States Environmental Protection Agency), 2004. Innovative technology verification report: Field measurement technology for mercury in soil and sediment. Ohio Lumex's RA-915+/RP-91C mercury analyser. EPA/600/R-03/147. Washington, p. 86

Fjellberg, A., 2007. The Collembola of Fennoscandia and Denmark, Part II: Entomobryomorpha and Symphypleona. Fauna Èntomol. Scand. 42, 1-264.

Fountain, M.T., Hopkin, S.P., 2005. Folsomia candida (Collembola): a "standard" soil arthropod. Annu. Rev. Entomol. 50, 201-222.

Garcia, M., 2004. Effects of pesticides on soil fauna: development of ecotoxicological test methods for tropical regions. Ecology and Development Series. Hohen Landwirtschaftlichen Fakultät, Universidade de Bonn, Germany, p. 281.

Garcia, M., Scheffczyk, A., Garcia, T., Römbke, J., 2011. The effects of the insecticide lambda-Cyhalothrin on the earthworm Eisenia fetida under experimental conditions of tropical and temperate regions. Environ. Pollut. 159, 398-400.

Greenslade, P., Vaughan, G.T., 2003. A comparison of Collembola species for toxicity testing of Australian soils. Pedobiologia 47, 171-179.

Grigal, D.F., 2003. Mercury sequestration in forests and peatlands: a review. J. Environ. Qual. 32, 393-405.

Holmstrup, M., Aubail, A., Damgaard, C., 2008. Exposure to mercury reduces cold tolerance in the springtail Folsomia candida. Comp. Biochem. Physiol. C: Pharmacol. Toxicol. 148, 172-177.

Hopkin, S.P., 2007. A key to the Collembola (Springtails) of Britain and Ireland. Field Studies Council: Bringing Environmental Understanding to All, pp. 1-252.

ISO (International Organization for Standardization), 1999. ISO 11267. Soil Quality Inhibition of Reproduction of Collembola (Folsomia candida) by Soil Pollutants. Geneva, Switzerland.

ISO (International Organization for Standardization), 2011. ISO 17512-2. Soil Quality-Avoidance Test for Testing the Quality of Soils and Effects of Chemicals on Behaviour - Part 2: Test with Collembolan (Folsomia candida). Geneva, Switzerland.

Janssens, T.K.S., Roelofs, D., Van Straalen, M., 2009. Molecular mechanisms of heavy metal tolerance and evolution in invertebrates. Insect Sci. 16, 3-18.

Juillerat, J.I., Ross, D.S., Bank, M.S., 2012. Mercury in litterfall and upper soil horizons in forested ecosystems in Vermont, USA. Environ. Toxicol. Chem. 31 (8), $1720-1729$.

Kabata-Pendias, A., 2011. Trace elements in soils and plants, 4th ed. CRC Press, Taylor and Francis Group, USA, p. 534.

Krogh, P.H., Amorim, M.J.de B., Andrés, P., Bakonyi, G., van Slooten, K.B., Domene, X. Geujin, I., Kaneko, N., Knäbe, S., Kocí, V., Lana, J., Moser, T., Princz, J., Schaefer, M., Scott-Fordsmand, J.J., Stubberud, H., Wilke, B.-M., 2008. Toxicity testing with the collembolans Folsomia fimetaria and Folsomia candida and the results of a ringtest. Miljoministeriet. Denmark, p. 44.

Lewinsohn, T.M., Prado, P.I., 2005. How many species are there in Brazil? Conserv. Biol. 19 (3), 619-624.

Liu, F., Zheng, Y.M., Zhang, L.M., Luan, Y.X., He, J.Z., 2010. Effects of mercury on reproduction, avoidance, and heat shock protein gene expression of the soil springtail Folsomia candida. Environ. Toxicol. Chem. 29, 654-659.

Liu, F., Cheng, H., Yanga, K., Zhao, C., Liu, Y., Peng, M., Li, K., 2014. Characteristics and influencing factors of mercury exchange flux between soil and air in Guangzhou City. J. Geochem. Explor. 139, 115-121.

Lock, k, Janssen, C.R., 2001. Ecotoxicity of mercury to Eisenia fetida, Enchytraeus albidus and Folsomia candida. Biol. Fertil. Soils 34 (4), 219-221.

Luo, W., Verweij, R.A., Van Gestel, C.A.M., 2014. Assessment of the bioavailability and toxicity of lead polluted soils using a combination of chemical approaches and bioassays with the collembolan Folsomia candida. J. Hazard. Mater. 280, 524-530

Marshall, V.G., Kevan, K.M., 1962. Preliminary observations on the biology of Folsomia candida Willem, 1902 (Collembola: Isotomidae). Can. Entomol. 94, $575-586$.

Marumoto, K., Hayashi, M., Takami, A., 2015. Atmospheric mercury concentrations at two sites in the Kyushu Islands, Japan, and evidence of long-range transport from East Asia. Atmos. Environ. 117, 147-155.

Mendonç, M.C. Queiroz, G.C., da Silveira, T.C., 2015. Two new species of Proisotoma Börner, 1901 from Southeastern Brazil (Collembola: Isotomidae). Soil Org. 
87 (1), 51-60.

Nakamori, T., Yoshida, S., Kubota, Y., Ban-nai, T., Kaneko, N., Hasegawa, M., Itoh, R., 2008. Sensitivity to cadmium of the standard test species Folsomia candida compared to two other species, Onychiurus yodai and Sinella umesaoi (Collembola). Eur. J. Soil Biol. 44, 266-270.

Niklasson, M., Petersen, H., Parker, E.D., 2000. Environmental stress and reproductive mode in Mesaphorura macrochaeta (Tullbergiinae, Collembola). Pedobiologia 44, 476-488.

Niemeyer, J.C., Moreira-Santos, M., Ribeiro, R., Rutgers, M., Nogueira, M.A., da Silva, E.M., Sousa, J.P., 2015. Ecological risk assessment of a metal-contaminated are in the tropics. Tier II: Detailed assessment. PLoS One 10, e0141772.

Nogueira, A.R.A., Souza, B.G., 2005. Manual de laboratório: Solo, água, nutrição vegetal, nutrição animal e alimentos, Embrapa, São Carlos.

Nursita, A.I., Singh, B., Lees, E., 2005a. The effects of cadmium on population, growth and cadmium accumulation of Proisotoma minuta in some Australian soils. Aust. J. Ecotoxicol. 11, 73-83.

Nursita, A.I., Singh, B., Lees, E., 2005b. The effects of cadmium, copper, lead and zinc on the growth and reproduction of Proisotoma minuta Tullberg (Collembola). Ecotoxicol. Environ. Saf. 60, 306-314.

Nursita, A.I., Singh, B., Lees, E., 2009. Cadmium bioaccumulation in Proisotoma minuta in relation to bioavailability in soils. Ecotoxicol. Environ. Saf. 72, $1767-1773$.

OECD (Organization for Economic Cooperation and Development), 1984. Guideline for the Testing of Chemicals n. 207. Earthworm acute toxicity tests. Paris, France.

Quijas, S., Balvanera, P., 2013. Biodiversity and ecosystem services, Encyclopedia of Biodiversity, Second Edition Academic Press, Waltham, pp. 341-356.

Richardson, J.B., Friedland, A.J., Engerbretson, T.R., Kaste, J.M., Jackson, B.P., 2013. Spatial and vertical distribution of mercury in upland forest soils across the northeastern United States. Environ. Pollut. 182 (1), 127-134.

Sakuma, M., 1998. Probit analysis of preference data. Appl. Entomol. Zool., 33, pp. 339-347. 〈http://www.ars.usda.gov/Services/docs.htm?docid=11284〉. accessed (19.12.15).

Salmon, S., Ponge, J.-F., 1999. Distribution of Heteromurus nitidus (Hexapoda, Collembola) according to soil acidity: interactions with earthworms and predator pressure. Soil Biol. Biochem. 31, 1161-1170.

Salmon, S., Ponge, J.F., 2012. Species traits and habitats in springtail communities: regional scale study. Pedobiologia 55, 295-301.

Salmon, S., Ponge, J.P., Gachet, S., Deharveng, L., Lefebvre, N., Delabrosse, F., 2014. Linking species, traits and habitat characteristics of Collembola at European scale. Soil Biol. Biochem. 75, 73-85.

Sandifer, R.D., Hopkin, S.P., 1996. Effects of pH on the toxicity of cadmium, copper, lead and zinc to Folsomia candida Willen, 1902 (Collembola) in a standard laboratory test system. Chemosphere 33, 2475-2486.

Sandifer, R.D., Hopkin, S.P., 1997. Effects of temperature on the relative toxicities of $\mathrm{Cd}, \mathrm{Cu}, \mathrm{Pb}$, and $\mathrm{Zn}$ to Folsomia candida (Collembola). Ecotoxicol. Environ. Saf. 37, 125-130.

Santorufo, L., van Gestel, C.A.M., Maisto, G., 2012. Ecotoxicological assessment of metal-polluted urban soils using bioassays with three soil invertebrates. Chemosphere 88, 418-425.

Schroeder, W.H., Munthe, J., 1998. Atmospheric mercury - an overview. Atmos. Environ. 32 (5), 809-822.

Silva-Filho, E.V., Oliveira, R.R., Machado, W., Sella, S.M., Lacerda, L.D., 2006. Mercury deposition through litterfall in an Atlantic Forest at Ilha Grande, southeast Brazil. Chemosphere 65 (11), 2477-2484.

Slotsbo, S., Heckmann, L.-H., Damgaard, C., Roelofs, D., de Boer, T., Holmstrup, M., 2009. Exposure to mercury reduces heat tolerance and heat hardening ability of the springtail Folsomia candida. Comp. Biochem. Physiol. C: Pharmacol. Toxicol. 150, 118-123.

Snider, R.J., Butcher, J.W., 1973. The life history of Folsomia candida (Willem) (Collembola: Isotomidae) relative to temperature. Gt. Lakes Entomol. 6, 97-106.

Soares, L.C., Egreja Filho, F.B., Linhares, L.A., Windmoller, C.C., Yoshida, M.I., 2015 Accumulation and oxidation of elemental mercury in tropical soils. Chemosphere 134, 181-191.

Son, J., Mo, H.-ho, Kim, J.-hong, Ryoo, M.I.I., Cho, K., 2007a. Effect of soil organic matter content and $\mathrm{pH}$ on toxicity of cadmium to Paronychiurus kimi (Lee) (Collembola). J. Asia-Pac. Entomol. 10 (1), 55-61.

Son, J., Ryoo, M.I.I., Jung, J., Cho, K., 2007b. Effects of cadmium, mercury and lead on the survival and instantaneous rate of increase of Paronychiurus kimi (Lee) (Collembola). Appl. Soil Ecol. 35, 404-411.

Sterzyńska, M., Shrubovych, J., Kaprus, I., 2014. Effect of hydrologic regime and forest age on Collembola in riparian forests. Appl. Soil Ecol. 75, 199-209.

Teixeira, D.C., Montezuma, R.C., Oliveira, R.R., Silva-Filho, E.V., 2012. Litterfall mercury deposition in Atlantic forest ecosystem from SE - Brazil. Environ. Pollut 164 (1), 11-15.

Tipping, E., Poskitt, J.M., Lawlor, A.J., Wadsworth, R.A., Norris, D.A., Hall, J.R., 2011. Mercury in United Kingdom topsoils; concentrations, pools, and critical limit exceedances. Environ. Pollut. 159, 3721-3729.

UNEP (United Nations Environment Programme), 2013. Global Mercury Assessment: Sources, Emissions, Releases and Environmental Transport. UNEP Chemicals Branch, Geneva, Switzerland.

Van Straalen, N.M., Burghouts, T.B.A., Doornhof, M.J., Groot, G.M., Janssen, M.P.M., Joose, E.N.G., Van Meerendonk, J.H., Theeuwen, J.P.J.J., Verhoef, H.A., 1987. Efficiency of lead and cadmium excretion in populations of Orchesella Cincta (Collembola) from various contaminated forest soils. J. Appl. Ecol. 24, 953-968. 